\title{
Incorporation of Fibrin Into a Collagen-Glycosaminoglycan Matrix Results in a Scaffold With Improved Mechanical Properties and Enhanced Capacity to Resist Cell-Mediated Contraction
}

\author{
Claire Brougham \\ Technological University Dublin, claire.brougham@tudublin.ie \\ Tanya J. Levingstone \\ RCSI \\ Stefan Jockenhoevel \\ E⿰lllw this and additional works at: https://arrow.tudublin.ie/biodevart \\ Part of the Biology and Biomimetic Materials Commons, Biomaterials Commons, Molecular, Cellular, \\ and Tissue Engineering Commons, and the Structural Biology Commons \\ See next page for additional authors
}

\section{Recommended Citation}

Brougham, C. et al. Incorporation of fibrin into a collagen-glycosaminoglycan matrix results in a scaffold with improved mechanical properties and enhanced capacity to resist cell-mediated contraction. Acta Biomaterialia, August 2015. doi:10.1016/j.actbio.2015.08.022

This Article is brought to you for free and open access by the Biomedical Devices and Assistive Technology Research Group at ARROW@TU Dublin. It has been accepted for inclusion in Articles by an authorized administrator of ARROW@TU Dublin. For more information, please contact arrow.admin@tudublin.ie, aisling.coyne@tudublin.ie,gerard.connolly@tudublin.ie. Funder: This study has received funding from the Irish Heart Foundation (Grant number 1045940), the European Research Council under the European Community's Seventh Framework Programme (FP7/2007-2013) under European Research Council grant agreement $n^{\circ} 239685$ and the School of Mechanical and Design Engineering, DIT; Allison Cudsworth; FOCUS Institute, DIT for SEM work

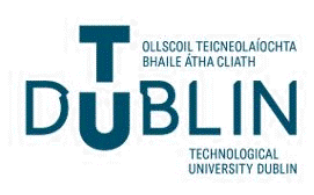




\section{Authors}

Claire Brougham, Tanya J. Levingstone, Stefan Jockenhoevel, Thomas C. Flanagan, and Fergal J. O'Brien 


\section{Accepted Manuscript}

Incorporation of fibrin into a collagen-glycosaminoglycan matrix results in a scaffold with improved mechanical properties and enhanced capacity to resist cell-mediated contraction

Claire M. Brougham, Tanya J. Levingstone, Stefan Jockenhoevel, Thomas C. Flanagan, Fergal J. O’Brien

PII:

DOI:

Reference:

To appear in:

Received Date:

Revised Date:

Accepted Date:

$$
\text { S1742-7061(15)30066-0 }
$$$$
\text { http://dx.doi.org/10.1016/j.actbio.2015.08.022 }
$$

$$
\text { ACTBIO } 3836
$$

\section{Acta Biomaterialia}

27 February 2015

11 August 2015

18 August 2015

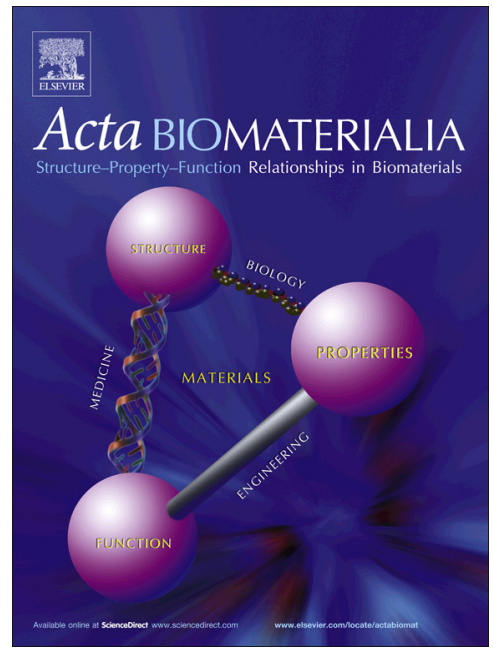

Please cite this article as: Brougham, C.M., Levingstone, T.J., Jockenhoevel, S., Flanagan, T.C., O’Brien, F.J., Incorporation of fibrin into a collagen-glycosaminoglycan matrix results in a scaffold with improved mechanical properties and enhanced capacity to resist cell-mediated contraction, Acta Biomaterialia (2015), doi: http:// dx.doi.org/10.1016/j.actbio.2015.08.022

This is a PDF file of an unedited manuscript that has been accepted for publication. As a service to our customers we are providing this early version of the manuscript. The manuscript will undergo copyediting, typesetting, and review of the resulting proof before it is published in its final form. Please note that during the production process errors may be discovered which could affect the content, and all legal disclaimers that apply to the journal pertain. 


\section{Incorporation of fibrin into a collagen-glycosaminoglycan matrix results in a scaffold with improved mechanical properties and enhanced capacity to resist cell-mediated contraction.}

Authors

Claire M. Brougham, BEng, MEngSc ${ }^{1,2,3}$,

Tanya J. Levingstone, BEng, MSc, PhD ${ }^{1,3,4}$

Stefan Jockenhoevel, $\mathrm{MD}^{5}$

Thomas C. Flanagan, BSc, $\mathrm{PhD}^{6}$

Fergal J. O’Brien BA, BAI, PhD, FAS, CEng, FIEI ${ }^{1,3,4}$

\section{Affiliations}

${ }^{1}$ Tissue Engineering Research Group, Dept. of Anatomy, Royal College of Surgeons in Ireland, 123 St. Stephen's Green, Dublin 2, Ireland.

${ }^{2}$ School of Mechanical and Design Engineering, Dublin Institute of Technology, Bolton St, Dublin 1, Ireland.

${ }^{3}$ Advanced Materials and Bioengineering Research (AMBER) Centre, RCSI \& TCD.

${ }^{4}$ Trinity Centre for Bioengineering, Trinity College Dublin, Dublin 2, Ireland.

${ }^{5}$ AME-Helmholtz Institute for Biomedical Engineering, Pauwelsstr. 20, 52074 Aachen, RWTH Aachen University, Germany.

${ }^{6}$ School of Medicine \& Medical Science, University College Dublin, Dublin 4, Ireland.

\section{Corresponding author:}

Prof. Fergal O’Brien,

Department of Anatomy,

Royal College of Surgeons in Ireland,

123 St. Stephen's Green,

Telephone Number: +353 (0)1-402-2149

FAX Number: $+353(0) 1-402-2355$

Email: fjobrien@rcsi.ie 


\section{Abstract:}

Fibrin has many uses as a tissue engineering scaffold, however many in vivo studies have shown a reduction in function resulting from the susceptibility of fibrin to cell-mediated contraction. The overall aim of the present study was to develop and characterise a reinforced natural scaffold using fibrin, collagen and glycosaminoglycan (FCG), and to examine the cell-mediated contraction of this scaffold in comparison to fibrin gels. Through the use of an injection loading technique, a homogenous FCG scaffold was developed. Mechanical testing showed a six-fold increase in compressive modulus and a thirty-fold increase in tensile modulus of fibrin when reinforced with a collagen-glycosaminoglycan backbone structure. Human vascular smooth muscle cells (vSMCs) were successfully incorporated into the FCG scaffold and demonstrated excellent viability over 7 days, while proliferation of these cells also increased significantly. VSMCs were seeded into both FCG and fibrin-only gels at the same seeding density for 7 days and while FCG scaffolds did not demonstrate a reduction in size, fibrin-only gels contracted to $10 \%$ of their original diameter. The FCG scaffold, which is composed of natural biomaterials, shows potential for use in applications where dimensional stability is crucial to the functionality of the tissue.

\section{Kevwords:}

Fibrin

Tissue Engineering

Cardiovascular scaffold

Heart valve 


\section{Introduction}

Scaffolds for tissue engineering (TE) provide a template for cells to lay down extracellular matrix (ECM). Biocompatibility and ease of sterilisation are basic scaffold requirements, while scaffold geometry, degradation kinetics and mechanical properties each play a key role in the generation of the tissue construct in vitro (Jana et al. 2014; Li et al. 2014). There are unique challenges associated with the design of scaffolds for applications where the shape and dimensional stability of the scaffold is critical to its function. For example, heart valve constructs that have undergone a period of in vitro remodelling must be able to withstand the challenging haemodynamic environment at the donor site from the moment of implantation. If the construct does not function correctly, i.e. with full coaptation of the leaflets, it will not be able to sustain its role as a valve over the long term. To date, a variety of scaffolds have been proposed for heart valve TE, using both synthetic (Hoerstrup et al. 2002; Ramaswamy et al. 2010; Sodian et al. 2000; Sant et al. 2013; Kalfa et al. 2010; Schmidt et al. 2010; Mol et al. 2006) and biological (Flanagan et al. 2009; Yamanami et al. 2010; Weber et al. 2013; Syedain et al. 2013) materials and these have demonstrated varying degrees of success once implanted in vivo. Of these options, we believe that fully biological heart valves hold greater promise than synthetic or decellularised valves for the development of long-term heart valve replacements which will have the ability to grow and remodel with the patient.

Fibrin, due to its inherent biocompatibility and plasmin-controlled remodelling (Collen 2001), shows particular promise. Fibrin is a naturally-occurring polymer involved in the wound-healing response. It can be extracted from the blood of a potential patient, creating a biocompatible, autologous material, whose peptide chains and integrin binding sites encourage cell adhesion, migration, proliferation, and angiogenesis (Haisch et al. 2000; Jockenhoevel et al. 2001; Weinandy et al. 2014). Fibrin can be used to encapsulate cells, creating a construct with a homogenous cell distribution and has been used in a range of applications including neural regeneration, wound healing, bone grafts, cartilage repair and cardiovascular applications (Ahmed et al. 2008). The rate of fibrin degradation can be controlled through the use of protease inhibitors (Cholewinski et al. 2009; Eyrich et al. 2007; Collen 2001) and fibrin also encourages ECM deposition and retention by the cells that it encapsulates (Ahmann et al. 2010; Ameer et al. 2002; Ye, Zünd, Benedikt, et al. 2000). Conversely, the weak mechanical properties of fibrin and susceptibility to cell-mediated contraction mean that sustaining dimensional stability is very difficult when using fibrin as a lone scaffold material. Many in vivo studies have shown a reduction in function resulting from this cell-mediated contraction (Flanagan et al. 2009; Syedain et al. 2011; Weber et al. 2013). In light of this, fibrin has been incorporated in combination with biomaterials such as hyaluronic acid (Lee \& Kurisawa 2013), polyethylene oxide (Akpalo et al. 2011) and alginate 
(Shikanov et al. 2009) in interpenetrating networks. Fibrin has also been combined with collagen in mixed gels (Cummings et al. 2004), with a limited increase in mechanical properties reported. Additionally, fibrin has been used with porous, synthetic scaffolds (Gundy et al. 2008; Lesman et al. 2011; Mol et al. 2005; Moreira et al. 2014) and while this approach has improved the structural integrity of fibrin, acidic by-products are released during the subsequent degradation of the synthetic scaffold (Sung et al. 2004; Monfoulet et al. 2014; Busa \& Nuccitelli 1984).

The use of natural materials to reinforce a fibrin gel, with the aim of minimising cellmediated contraction of the fibrin gel, has not been examined in detail. Moreover, the literature shows that a stiffer scaffold has a greater resistance to cell-mediated contraction (Sheu et al. 2001; Keogh et al. 2010). Our research group has developed a range of collagenbased structures, with interconnected, homogenous pores and a dehydrated macrostructure for a variety of applications, from bone grafts to gene delivery (O'Brien et al. 2005; O’Brien et al. 2004; Keogh et al. 2010; Cunniffe et al. 2010; Roche et al. 2014; Tierney et al. 2012). The mechanical properties of the freeze-dried collagen can be customised using different manufacturing methods and constituents, for example, the addition of glycosaminoglycans (GAGs) has been shown to increase the stiffness of the collagen matrix (Gleeson et al. 2010; Haugh et al. 2011; O'Brien et al. 2004). Consequently, the present study hypothesises that a fibrin gel that is reinforced with a freeze-dried, collagen glycosaminoglycan (CG) structure will provide a more dimensionally stable scaffold for tissue engineering applications, by resisting cell-mediated contraction.

Hence, the overall aim of this study was to develop a fibrin-collagen-glycosaminoglycan (FCG) scaffold that could resist cell-mediated contraction and provide a dimensionally stable structure for tissue engineering applications. The specific objectives were (i) to develop methods of combining a fibrin gel and a CG matrix and to characterise the microstructure of the resultant FCG scaffolds; (ii) to investigate the tensile and compressive moduli of fibrin when reinforced with a CG matrix; (iii) to investigate the response of human vascular smooth muscle cells (vSMCs) to the FCG scaffold, and (iv) to examine the cell-mediated contraction of FCG scaffolds in comparison to fibrin gels alone.

\section{$\underline{2 \text { Materials and Methods }}$}

\subsection{Scaffold Fabrication}

\subsubsection{Fabrication and crosslinking of CG structure}

CG sheets were fabricated, as previously described, using a lyophilisation process ( $O$ 'Brien et al. 2005) with a collagen (type 1 bovine) (Integra Life Science, Plainsboro, NJ, USA) concentration of $0.75 \% \mathrm{w} / \mathrm{v}$ solution and a GAG (chondroitin sulphate) (Sigma-Aldrich, Arklow, Ireland) concentration of $0.044 \% \mathrm{w} / \mathrm{v}$ (Tierney et al. 2009). The concentrations used were based on previous characterisation work performed within the laboratory. The CG 
suspension was freeze-dried to a final freezing temperature of $-10^{\circ} \mathrm{C}$ using a freezing rate of $1 \%$ min, followed by subsequent drying, to produce a homogenous structure with an average pore size of $150 \mu \mathrm{m}$ and porosity of $99 \%$ (Haugh et al. 2010). Dehydrothermal treatment using a vacuum oven (Vacucell, MMM Group, Munich, Germany) at 0.05 bar and $105^{\circ} \mathrm{C}$, over 24 hours, was used to physically crosslink and sterilise the CG matrix (Haugh et al. 2009). Discs (15.8mm diameter, $2 \mathrm{~mm}$ high) of the sterile CG matrix were cut using a biopsy punch. These were chemically crosslinked using 1-ethyl-3-(3dimethylaminopropyl)carbodiimide (EDAC) in combination with $\mathrm{N}$-hydroxysuccinimide (NHS) as described previously (Haugh et al. 2011), with the difference of using ethanol as the solvent to further increase stiffness (Barnes et al. 2007). Discs were washed in decreasing concentrations of ethanol and stored in phosphate buffered saline (PBS) (SigmaAldrich) prior to use, which was always within 12 hours.

\subsubsection{Incorporation of fibrin into CG matrix}

Fibrin gels were fabricated as previously described (Jockenhoevel et al. 2001). Briefly, bovine fibrinogen (Sigma-Aldrich) was dissolved in PBS and dialysed against $4 \mathrm{~L}$ of tris-buffered saline (TBS) in 6,000-8,000MW dialysis tubing (Spectrum Labs, Breda, The Netherlands) overnight. After sterile filtration, the fibrinogen concentration was quantified by measuring the absorbance at 280nm using a spectrophotometer (Nanodrop 2000; Thermo Fisher Scientific, Delaware, USA). The final concentration of fibrinogen solution was adjusted to $10 \mathrm{mg} / \mathrm{ml}$ with PBS. To make fibrin gels of $1000 \mu \mathrm{l}, 75 \mu \mathrm{l}$ of $0.05 \mathrm{M} \mathrm{CaCl}_{2}, 350 \mu \mathrm{l}$ TBS and $75 \mu \mathrm{l}$ of $40 \mathrm{IU} / \mathrm{ml}$ of thrombin (Sigma-Aldrich), were pipetted into a 24 -well plate into which $500 \mu \mathrm{l}$ of the $10 \mathrm{mg} / \mathrm{ml}$ fibrinogen solution was added for subsequent polymerisation. After transferring the fibrin to an incubator at $37^{\circ} \mathrm{C}$ for 60 minutes, polymerisation was complete. To fabricate gels of different sizes, these ratios were maintained and the volume changed.

In order to fabricate the fibrin-collagen-GAG (FCG) scaffolds, two methods of fibrin incorporation into the CG matrix were investigated, drop-loading and injection loading, in order to assess the effect of each method on the resulting FCG microstructure (Fig. 1). Regardless of method, the crosslinked CG matrix was firstly soak-loaded with $\mathrm{CaCl}_{2}, \mathrm{TBS}$ and thrombin in the same concentrations and ratios as described above for the fibrin gels. Using the drop-loading technique, the fibrinogen was added on top of the CG matrix in a dropwise fashion using a pipette. For the injection loading technique, the fibrinogen was injected into the matrix in a repeatable circular pattern using a 27 gauge needle. All scaffolds were left to polymerise at $37^{\circ} \mathrm{C}$ for 60 minutes. For the injection-loaded scaffolds, the optimum volume of fibrin to incorporate into the CG matrix was also assessed. Total volumes fibrin of $250 \mu \mathrm{l}, 300 \mu \mathrm{l}, 350 \mu \mathrm{l}$ and $400 \mu \mathrm{l}$ were injected into CG matrix (diameter $15.8 \mathrm{~mm}$, thickness $2 \mathrm{~mm}$ ). These volumes were based on preliminary experimental work that showed that volumes of greater than $400 \mu \mathrm{l}$ could not be maintained within each matrix.

\subsection{Characterisation of Fibrin-Collagen-Glycosaminoglycan Scaffold}




\subsubsection{Histological staining of the FCG scaffold}

Histological analysis was used to investigate fibrin infiltration into the CG matrix. Samples were formalin-fixed, embedded in Jung Tissue freezing medium (Laboratory Instruments and Supplies, Ashbourne, Ireland) and cryosectioned (Leica CM 1950, Wetzlar, Germany) to a thickness of $10 \mu \mathrm{m}$, in both the transverse and longitudinal planes. Masson's Trichrome (Sigma-Aldrich) staining was performed using standard protocols by immersing in Bouin's solution, Biebrich scarlet-acid fuchsin, phosphotungstic/phosphomolybdic acid solution and aniline blue with the exclusion of haemotoxylin as no cells were present in these scaffolds. This process stained fibrin (red) and collagen (blue), allowing visualisation of both components in single sections. Samples were observed using a light microscope (ECLIPSE 90i; Nikon, Tokyo, Japan) and digital images were captured using the DS Ri camera and NIS elements software (Nikon).

\subsubsection{Microstructure of the FCG scaffold}

The microstructure of the FCG scaffolds was examined using scanning electron microscopy (SEM) (Hitachi SU6600 VP-SEM; Hitachi High Technologies America Inc., Clarksburg, USA). To examine the infiltration of fibrin throughout the CG matrix, cross sections at different positions within the FCG scaffolds were formalin-fixed and critical point dried (Quorum E3000 CPD; Quorum Technologies, East Sussex, UK), fixed to an adhesive carbon stub, and then sputter coated with palladium/gold using a Polaron sputter coater (Quorum Technologies). CG matrix and fibrin gels prepared in an identical manner were used as references to compare structural features. SEM imaging was performed at an accelerating voltage of $15 \mathrm{kV}$, utilising the secondary electron detector.

\subsubsection{Mechanical Characterisation of the FCG scaffold}

Uniaxial compressive and tensile tests were performed to assess the effect of reinforcing fibrin with a crosslinked, acellular CG matrix. All samples were tested using a mechanical testing machine (Zwick/Roell, Ulm, Germany) fitted with a $5 \mathrm{~N}$ load cell and were hydrated in PBS throughout the testing. Samples for compressive testing were as described in Section 2.1.2. For tensile testing, FCG scaffolds were produced in a dog-bone shape which were $63.5 \mathrm{~mm}$ long with a narrowed centre of $3 \mathrm{~mm}$ as per ASTM D638 (specimen type V)(ASTM D638 2014).. CG matrices and fibrin gels were also produced in this dog-bone shape as controls.

Compressive and tensile tests were conducted at a strain rate of $10 \%$ per minute as described by Haugh et al (Haugh et al. 2009). The modulus was defined as the slope of a linear fit to the stress-strain curve over $2-5 \%$ strain (Harley et al. 2007). Compressive and tensile testing was performed on three samples per scaffold type, each of which was tested in triplicate. 


\subsection{Bioactivity Analysis}

2.3.1 Cell culture and seeding into the FCG scaffold

A human VSMC cell line was purchased from ATCC (CRL-1999; LGC Standards, Middlesex, UK). VSMCs are a contractile cell type, which allowed an appropriate assessment of the ability of the FCG scaffold to resist cellular-induced contraction. VSMCs were cultured using the recommended complete growth media consisting of Ham's F-12K (ATCC 30-2004, LGC Standards), supplemented with: $10 \%$ foetal bovine serum (Sigma-Aldrich), $2 \%$ penicillin/streptomycin (Sigma-Aldrich), $50 \mu \mathrm{g} / \mathrm{mL}$ ascorbic acid (Sigma-Aldrich), 16 $\mu \mathrm{l} / \mathrm{ml} 1 \mathrm{x}$ ITS (Insulin, Transferrin, Selenium) (BD Biosciences, Oxford, UK), 10mM HEPES (4-(2hydroxyethyl)-1-piperazineethanesulfonic acid) (Sigma-Aldrich), $10 \mathrm{mM}$ TES (NTris(hydroxymethyl)methyl-2-aminoethanesulfonic acid) (Sigma-Aldrich) and $0.03 \mathrm{mg} / \mathrm{ml}$ endothelial cell growth supplement (Sigma-Aldrich). Subculturing procedures were as per the manufacturer's instructions, using trypsin-EDTA solution (Sigma-Aldrich) for cell detachment. The culture medium was changed every 2 days and cell number was calculated using a haemocytometer.

For all tests, cells were seeded at a density of 1,000 cells $/ \mathrm{mm}^{3}$ per scaffold for both FCG and fibrin-only gels (Murphy \& O'Brien 2010). Cells were initially suspended in the fibrinogen component of the fibrin and following injection, the FCG scaffolds were left to fully polymerise for 60 minutes at $37^{\circ} \mathrm{C}$. To prevent adhesion to the cell culture plastic, scaffolds were then transferred to sterile 6 well plates and $4 \mathrm{ml}$ of media were added per well, together with $20 \mu \mathrm{g} / \mathrm{ml}$ of aprotinin (Sigma-Aldrich), a protease inhibitor (Ahmed et al. 2007). The culture medium was changed every 2-3 days and scaffolds were cultured for up to 7 days.

2.3.2 Histological analysis of the cell distribution through the FCG scaffold over time Histological analysis was performed to investigate cell dispersal in the FCG scaffold. Cellseeded scaffolds were analysed at 3,5 and 7 days in both the transverse and longitudinal planes. Samples were sectioned as described earlier, and stained using Masson's Trichrome (Sigma-Aldrich) with the addition of Weigert's hematoxylin to counterstain the vSMCs (black). Digital images were captured using a light microscope (ECLIPSE 90i; Nikon) and the DS Ri camera and NIS elements software (Nikon).

\subsubsection{Cell Viability Analysis}

To assess the cellular viability within scaffolds, staining was performed using a Live/Dead kit (Molecular Probes, Eugene, OR, USA) according to the manufacturer's protocol at 3, 5 and 7 days post-cell seeding. Calcein was used to stain viable cells green and Ethd- 1 was used to stain dead cells red. Fluorescence microscopy was used to observe cell viability using the Leica DMIL Fluorescence microscope (Leica, Wetzlar, Germany).

\subsubsection{Cell Number Quantification}


The Quant-iT PicoGreen dsDNA kit (BD BioSciences) was utilised according to the manufacturer's protocol to assess cell number within the FCG scaffold at days $0,3,5$, and 7 . Briefly, $100 \mu \mathrm{l}$ of the PicoGreen reagent solution was added to samples containing the $0.2 \mathrm{M}$ carbonate 1\% TritonX (Fisher, Dublin, Ireland) cell lysate buffer and fluorescence was read at $538 \mathrm{~nm}$ using a Varioskan Flash plate reader (ThermoScientific, Dreieich, Germany) and Skanlt RE for Varioskan software. Sample fluorescence was compared to a standard curve to determine cell number.

\subsection{Cell-mediated Contraction Analysis}

The cell-mediated contraction of the fibrin and FCG scaffolds by the vSMCs was compared. The dimensions of both scaffold types were measured daily using Vernier callipers (Krunstoffwerke, Radionics, Dublin, Ireland) to assess scaffold contraction and graphed as percentage contraction versus day $0(n=9)$. Thickness was also measured on day $0,3,5$ and 7 using a micrometre. Scaffolds were unconstrained, and media was changed every 2-3 days.

\subsection{Statistical analysis}

Results are expressed as mean \pm standard deviation. Statistical significance was assessed using one-way analysis of variance (ANOVA), followed by Tukey post-hoc analysis. The sample size was $n=3$, except for the contraction assessment study, where $n=9$. $P<0.05$ values were considered statistically significant throughout. 


\section{Results}

\subsection{Scaffold Fabrication and Characterisation}

\subsubsection{Analysis of FCG scaffold microstructure}

Histological analysis of the FCG scaffolds fabricated using drop-loading and injection loading techniques revealed that fibrin was not evenly dispersed throughout the CG scaffold in the drop-loaded FCG scaffolds. Instead, it was concentrated on the loaded side of the CG scaffold, as shown in Fig. 2A. This inconsistent incorporation in the drop-loaded group was also evident in the SEM images, as shown in Fig. 2B \& C. In contrast, histological analysis of the scaffolds formed by injecting the fibrinogen component, showed excellent infiltration of fibrin throughout the CG matrix (Fig. 2D). Once more, the SEM images confirmed this, with a homogenous distribution of fibrin observed both in the transverse and longitudinal plane (Fig. 2E, F). The optimal FCG scaffold contained an infiltration ratio of $300 \mu$ l of fibrin, loaded within a $15.8 \mathrm{~mm}$ diameter, $2 \mathrm{~mm}$ high CG scaffold (Fig. 2D). At this volume ratio, the fibrin component is seen throughout the thickness of the CG scaffold, unlike at the lower volumes, where insufficient incorporation was observed. Interestingly, with a larger volume above this level, the CG and fibrin were found to separate from each other (Fig. 2G where $350 \mu \mathrm{l}$ of fibrin was added).

\subsubsection{Mechanical Characterisation of the FCG scaffold}

The compressive and tensile moduli of the FCG scaffold were found to be significantly higher than those of the fibrin-only gel (Fig. 3). Compressive testing of fibrin-only gels showed a compressive modulus of $0.49 \mathrm{kPa} \pm 0.1$, and when reinforced with the CG matrix this increased to $2.97 \mathrm{kPa} \pm 0.5$, demonstrating a six-fold increase in compressive modulus (Fig. $3 A$ ). The compressive modulus of the FCG scaffold was significantly lower ( $22 \%$ lower) than for the CG matrix $(3.83 \mathrm{kPa} \pm 0.4)$. The CG compressive modulus of elasticity presented here was stiffer than previously published CG data from this laboratory (Haugh et al. 2009), as a higher concentration of collagen was used. Tensile testing of fibrin-only gels showed a tensile modulus of $0.02 \mathrm{MPa} \pm 0.01$, and when reinforced with the CG matrix this increased to $0.6 \mathrm{MPa} \pm 0.1$, demonstrating a 30 -fold increase in tensile modulus (Fig. 3B). The tensile modulus of the FCG scaffold was not significantly different to the CG-only matrix (0.59MPa \pm $0.04)$.

\subsection{Bioactivity}

3.2.1 Histological analysis of cell distribution

VSMCs were successfully incorporated into the FCG scaffold, using the injection technique, with fibrin itself acting as the carrier material. To assess the distribution of cells throughout the FCG scaffold, Masson's Trichrome staining was completed on transverse and longitudinal sections at day 3 (Fig. 4A, B), day 5 and day 7 (Fig. 4C, D). This analysis showed cells to be distributed evenly both transversely and longitudinally throughout the FCG 
scaffolds. No clumping of cells was observed, with cells contacting areas of both fibrin and collagen.

\subsubsection{Cell Viability Assessment}

Having successfully infiltrated the FCG scaffold with cells, the viability of the cells was assessed using live/dead staining, which demonstrated that a high number of viable cells were observed at each time point (Fig. 5). No differences in viability were observed between cells in fibrin gels and in FCG scaffolds. Large numbers of live cells (green) were evident throughout all images and there were only a very small number of dead cells (red) (Fig. 5). Interestingly, there was also a noticeable increase in total live cell numbers over time, demonstrating the proliferation of the cells throughout the scaffold. At higher magnifications, a normal VSMC morphology was observed by day 7 and cells were seen to stretch around the CG pores (Fig. 5E). These results illustrate that the incorporation of fibrin into a CG matrix to form a FCG scaffold leads to an environment that supports cell viability and proliferation.

Cell proliferation over the 7 day culture period was quantified using a dsDNA PicoGreen assay (Fig. 6). A significant increase in dsDNA was observed at day 7 (compared to days 0 and 3 but not day 5) which confirmed the qualitative results seen in Fig. 5.

\subsection{Cell-mediated Contraction Study}

Diameter and thickness was directly measured each day revealing unchanged dimensions in the FCG scaffold (Fig. 7) over the 7 day period. On the other hand, fibrin-only gels which were seeded using the same seeding density, and containing the same fibrinogen concentration, contracted to $30 \%$ of their original diameter after day 1 and to $10 \%$ by day 3 (Fig. 7A). 


\section{Discussion}

The overall aim of this study was to develop a fibrin-collagen-glycosaminoglycan (FCG) scaffold which would provide a dimensionally stable substrate for tissue engineering applications, by resisting cellular-induced contraction. Using an injection method to incorporate fibrin into a CG matrix ensured that a homogenous distribution of fibrin was achieved throughout the CG structure. Fibrin alone has a low tensile and compressive modulus; however, when reinforced with a CG matrix, the tensile and compressive moduli increased 6-fold and 30-fold, respectively. VSMCs remained viable and proliferated within the FCG scaffold, which provided $100 \%$ resistance to cellular-induced contraction over 7 days. This resistance to offers convincing evidence that the FCG scaffold can provide a dimensionally stable system for tissue engineering applications. This fully natural scaffold containing fibrin, collagen and GAG offers many biological advantages for tissue engineering applications such as cartilage development and cardiovascular applications. The greatest potential for this material is perhaps in the cardiovascular field, with a particular focus on heart valves, where cell-mediated contraction of tissue-engineered devices has proven to be a problem in achieving functional repair tissue.

The use of an injection technique proved to be a suitable methodology for achieving a homogenous distribution of fibrin throughout the CG matrix, and this was demonstrated through histological analysis and SEM imaging. Uniformly infiltrating a porous natural polymer matrix with fibrin, before the fibrin polymerised posed a major challenge and droploading of fibrin onto the CG matrix proved unsuccessful, as a barrier of polymerised fibrin blocked the passage of the remaining fibrin through the CG structure. The volume ratio of fibrin to CG matrix was also assessed and a volume of $300 \mu \mathrm{l}$ of fibrin per $15.8 \mathrm{~mm}$ diameter, $2 \mathrm{~mm}$ high CG matrix, was found to be optimal. This represented approximately $0.8 \mu \mathrm{l}$ of fibrin per $\mathrm{mm}^{3}$ of CG matrix. Interestingly, a higher volume ratio of fibrin to CG was more difficult to physically integrate into the $C G$ matrix in the time prior to polymerisation.

Reinforcing fibrin with a CG matrix resulted in an increase in mechanical properties of the FCG scaffold. This increase in compressive and tensile moduli is explained by the framework of the CG struts within the FCG scaffold which reinforced the fibrin gel. The CG struts resist the applied load and result in a higher modulus for the FCG scaffold, than for fibrin gels. This was most obvious with regards to the tensile modulus, which increased 30 -fold. There was no significant difference between the tensile moduli of the CG matrix and the FCG scaffolds. We propose that as fibrin gel has a low tensile modulus in comparison to the CG tensile modulus, it adds no resistance to alignment of the CG pores at under tension (Harley et al. 2007). However, the realignment of CG pores under compression was hindered by the presence of the fibrin, thus resulting in a $22 \%$ reduction of compressive modulus for FCG than for CG matrix alone. The tensile strength of fibrin is difficult to measure due to its gellike properties, thus it is not widely reported in the literature. In this study, all materials 
were polymerised in the dogbone shape enabling the measurement of their tensile properties. Fibrin has previously been combined with polyglycolic acid, hyaluronic acidtyramine and collagen (van Vlimmeren et al. 2013; Lee \& Kurisawa 2013; Cummings et al. 2004; Rowe et al. 2007; Hokugo et al. 2006) and while these combinations increased the mechanical properties of fibrin, the resistance to cell-mediated contraction remained minimal. This was due perhaps to the bonding between the materials. However, it is not necessarily the case that the stiffer the scaffold the better, as matrix stiffness also has the ability to regulate cell motility, proliferation and differentiation in various cell types (Discher et al. 2005; Pho et al. 2008; Yip et al. 2009; Engler et al. 2006; Haugh et al. 2011). Additionally, many of these studies (van Vlimmeren et al. 2013; Lee \& Kurisawa 2013; Cummings et al. 2004; Rowe et al. 2007; Hokugo et al. 2006) did not report strong cell viability.

Using collagen and GAG as reinforcement materials for a fibrin gel in this study has many advantages. Firstly, fibrin, collagen and GAGs are all natural materials which degrade enzymatically and the rate of degradation can be controlled through the use of protease inhibitors unlike synthetic materials which degrade in bulk (Shah et al. 2008). This correlation between degradation and tissue formation is important to ensure that the newly formed tissue does not contract. The Masson's Trichrome images here (Fig. 4) show that after 7 days in culture, both fibrin and CG are still present within the scaffold. As collagen is the building block for many biological tissues, it is advantageous to include it in a scaffold due to its ability to encourage normal biological functions in cells. Fibrin promotes ECM synthesis in the cells that it houses while also retaining deposited ECM due to the gel-like nature of the biomaterial. Fibrin, collagen and GAGs together have proven to be a suitable environment for both cardiovascular (Flanagan et al. 2006; van Vlimmeren et al. 2013; Alfonso et al. 2013; Neidert \& Tranquillo 2006) and cartilage applications (Eyrich et al. 2007; Deponti et al. 2014). GAGs such as chondroitin sulphate and hyaluronic acid are found abundantly in the cardiac cushion, from which valvulogenesis occurs, and studies have shown that the signalling molecules contained within these GAGs, regulate further heart valve development (Armstrong \& Bischoff 2004; Person et al. 2005; Eckert et al. 2012). When designing a scaffold for heart valve applications where the ability to repair and grow the tissue in vivo may be required, this can only be advantageous. GAGs are also present within the cartilage ECM, with chondroitin sulphate being the main component and hyaluronic acid, keratan sulphate and dermatan sulfate also present. Chondroitin sulphate has been shown to stimulate chondrogenesis in vitro and to promote cellular ingrowth and cartilaginous tissue formation in vivo (van Susante JLC et al. 2001; Buma et al. 2003).

When vSMCs were incorporated within the fibrin, an even distribution of cells throughout the FCG scaffold was achieved, as the fibrin polymerised quickly, securing the cells in position. This seeding process proved very efficient, demonstrated by the high cell retention levels seen. Notably, an initial homogenous cell distribution, as shown in this study, has 
been linked with strong ECM production (Kim et al. 1998). In contrast, distribution and attachment of cells in many scaffolds require cells to migrate through from one side, which exposes the risk of low cell attachment, making the scaffolds unsuitable for tissue development (Zund et al. 1999; Ye, Zünd, Jockenhoevel, et al. 2000). As demonstrated through live/dead staining and DNA quantification, the increase in cell numbers over the 7 days showed proliferation within the scaffold, leading to a high cell density. The reduction in cell number between days 5 and 7 in this scaffold is not statistically significant, and should be viewed as normal experimental variation. While there are some dead cells observed by day 7 in Fig. 5(D and E), overall cell viability is high (Fig. 5) with a statistical increase in cell number overall (Fig. 6). Together, these findings have positive clinical implications, as the efficient seeding process, and the ability of the FCG scaffold to support proliferation, would ensure fewer donor cells were required prior to the construction of regenerated tissue.

Fibrin has many uses as a tissue engineering scaffold, however many in vivo studies have shown a reduction in function resulting from the susceptibility of fibrin to cell-mediated contraction. Over seven days in culture, the FCG scaffold developed in this study resisted contraction by vSMCs, thereby achieving the primary aim of the study. Three separate factors may have influenced the ability of the FCG scaffold to resist contraction. Firstly, increased stiffness of the substrate, due to crosslinking, has been reported to reduce cellmediated contraction (Syedain et al. 2009; Sheu et al. 2001). FCG is a stiffer material than fibrin alone and so its resistance to deformation and bending is higher. The crosslinking of the CG matrix ensures that this stiffness is representative of the microstructure of the matrix and not a bulk material property. This ensures that at a size scale relevant to the cells encapsulated, the microstructure of CG struts resists the cell-mediated contraction. Valvular interstitial cells (VICs) have demonstrated the ability to sense their biomechanical environment resulting in pathological differentiation in vitro to osteoblast lineages. This has been attributed to a combination of both culturing on matrices with a compressive stiffness of higher than $\sim 110 \mathrm{kPa}$ and biochemical changes resulting in an increase in cell stiffness (Wyss et al. 2012; Yip et al. 2009; Merryman et al. 2007). This suggests that while the FCG scaffold is stiff enough to resist cellular-induced contraction, this stiffness will not cause calcification of cells. In fact, native porcine aortic heart valves have a reported stiffness of $703 \mathrm{kPa}$ and have an ultimate tensile strength of $1450 \mathrm{kPa}$ (Merryman, Huang, et al. 2006; Merryman, Engelmayr, et al. 2006). Secondly, an increase in collagen density has been reported to reduce cell-mediated contraction (Legant et al. 2009). The concentrations of both collagen and GAG utilised in this study were optimised to provide the most stable combination of each macromolecule. $0.75 \%$ collagen $\mathrm{w} / \mathrm{v}$ is a higher concentration than used for orthopaedic applications in our lab (Tierney et al. 2009; Keogh et al. 2010), however, once infiltrated with fibrin, other concentrations did not have the inherent structural stability, even when crosslinked, to endure handling and manipulation when infiltrated with fibrin during experiments. Thirdly, GAGs have also been shown to reduce cell-mediated contraction (van Vlimmeren et al. 2013). In studies where minimising 
contraction of fibrin was examined, the amount of GAGs available to the tissue had a direct impact on the level of cell contraction that occurred, with greater amounts of GAG leading to lower cell contraction. This was hypothesised to be due to the damping effect of the GAGs, however the types of GAG in the study were not determined (van Vlimmeren et al. 2013). From a heart valve perspective, the spongiosa layer of the heart valve, which is comprised primarily of GAGs, works as a cushion allowing the spongiosa and ventricularis to shear relative to each other and the water retained by the GAGs also provides a damping effect to the tissue (Misfeld \& Sievers 2007). Findings from the static analysis suggest that when exposed to a dynamic environment, these materials will continue to demonstrate appropriate dimensional stability and resistance to proteolytic activity and haemodynamic forces. This clearly warrants further investigation.

Taken together, the results herein provide compelling evidence that the FCG scaffold developed here provides a natural scaffold which can resist cell-mediated contraction normally seen in fibrin scaffolds. The structure of the FCG scaffold is homogenous and provides higher compressive and tensile moduli than fibrin alone. Cells can be incorporated efficiently providing an excellent cell distribution of viable cells which proliferate over time. Over 7 days in unconstrained culture, the dimensions of the FCG scaffold did not change, showing an ability to resist cellular-induced contraction, while still maintaining cell viability. As collagen also forms the main component of a range of other tissue types within the body, the FCG scaffold presented has potential for applications in areas such as cartilage repair, wound healing and in applications where angiogenesis is important (Weinandy et al. 2014) due to its mechanical properties and unique biological framework. We are currently focussing on cardiovascular applications for this material, specifically as a heart valve scaffold.

\section{Conclusion}

This study presents the development of a natural fibrin-collagen-glycosaminoglycan scaffold with unique mechanical and biological properties. Using a technique where fibrin is injected into a collagen-glycosaminoglycan porous matrix, an effective manufacturing process that ensured excellent integration of all scaffold constituents was established. The compressive and tensile moduli of this FCG scaffold were significantly increased, in comparison to fibrin alone. Consistent cell viability, with an increase in VSMC proliferation over 7 days, was also demonstrated. Crucially, the ability of this FCG scaffold to resist cell-mediated contraction was demonstrated, with no change in scaffold dimensions over 7 days. These results show the potential of this material for use in applications where dimensional stability is crucial to the functionality of the tissue and also where a solution comprised of all natural materials makes a more attractive option than currently available materials.

Acknowledgements 
Irish Heart Foundation (grant number 1045940); Allison Cudsworth; FOCUS Institute, DIT for SEM work. 
References:

Ahmann, K. a et al., 2010. Fibrin degradation enhances vascular smooth muscle cell proliferation and matrix deposition in fibrin-based tissue constructs fabricated in vitro. Tissue engineering. Part A, 16(10), pp.3261-70. Available at: http://www.pubmedcentral.nih.gov/articlerender.fcgi?artid=2947425\&tool=pmcentrez \&rendertype=abstract [Accessed September 22, 2014].

Ahmed, T. a E., Dare, E. V \& Hincke, M., 2008. Fibrin: a versatile scaffold for tissue engineering applications. Tissue engineering. Part B, Reviews, 14(2), pp.199-215. Available at: http://www.ncbi.nlm.nih.gov/pubmed/18544016 [Accessed January 31, 2013].

Ahmed, T. a E., Griffith, M. \& Hincke, M., 2007. Characterization and inhibition of fibrin hydrogel-degrading enzymes during development of tissue engineering scaffolds. Tissue engineering, 13(7), pp.1469-1477. Available at: http://www.ncbi.nlm.nih.gov/pubmed/17518706 [Accessed November 9, 2012].

Akpalo, E. et al., 2011. Fibrin-polyethylene oxide interpenetrating polymer networks: new self-supported biomaterials combining the properties of both protein gel and synthetic polymer. Acta biomaterialia, 7(6), pp.2418-27. Available at: http://www.sciencedirect.com/science/article/pii/S1742706111001127 [Accessed March 5, 2014].

Alfonso, A.R. et al., 2013. Glycosaminoglycan entrapment by fibrin in engineered heart valve tissues. Acta biomaterialia, 9(9), pp.8149-57. Available at: http://www.ncbi.nlm.nih.gov/pubmed/23791855 [Accessed August 14, 2013].

Ameer, G. a, Mahmood, T. a \& Langer, R., 2002. A biodegradable composite scaffold for cell transplantation. Journal of orthopaedic research : official publication of the Orthopaedic Research Society, 20(1), pp.16-9. Available at: http://www.ncbi.nlm.nih.gov/pubmed/11853084.

Armstrong, E.J. \& Bischoff, J., 2004. Heart valve development: endothelial cell signaling and differentiation. Circulation research, 95(5), pp.459-70. Available at: http://www.pubmedcentral.nih.gov/articlerender.fcgi?artid=2810618\&tool=pmcentrez \&rendertype=abstract [Accessed July 9, 2014].

ASTM D638, 2014. No Title. , p.Standard Test Method for Tensile Properties of Pla. Available at: www.astm.org.

Barnes, C.P. et al., 2007. Cross-linking electrospun type II collagen tissue engineering scaffolds with carbodiimide in ethanol. Tissue engineering, 13(7), pp.1593-605. Available at: http://www.ncbi.nlm.nih.gov/pubmed/17523878 [Accessed November 20, 2012]. 
Buma, P. et al., 2003. Cross-linked type I and type II collagenous matrices for the repair of full-thickness articular cartilage defects--a study in rabbits. Biomaterials, 24(19), pp.3255-63. Available at: http://www.ncbi.nlm.nih.gov/pubmed/12763453 [Accessed October 20, 2014].

Busa, W. \& Nuccitelli, R., 1984. Metabolic regulation via intracellular pH. American Journal of Physiology, 246, pp.409-438. Available at: http://ajpregu.physiology.org/content/246/4/R409.short [Accessed July 11, 2014].

Cholewinski, E. et al., 2009. Tranexamic acid--an alternative to aprotinin in fibrin-based cardiovascular tissue engineering. Tissue engineering. Part A, 15(11), pp.3645-53. Available at: http://www.ncbi.nlm.nih.gov/pubmed/19496679 [Accessed August 23, 2013].

Collen, D., 2001. Ham-Wasserman lecture: role of the plasminogen system in fibrinhomeostasis and tissue remodeling. Hematology / the Education Program of the American Society of Hematology. American Society of Hematology. Education Program, pp.1-9. Available at: http://www.ncbi.nlm.nih.gov/pubmed/11722975 [Accessed January 14, 2015].

Cummings, C.L. et al., 2004. Properties of engineered vascular constructs made from collagen, fibrin, and collagen-fibrin mixtures. Biomaterials, 25(17), pp.3699-3706. Available at: http://www.ncbi.nlm.nih.gov/pubmed/15020145.

Cunniffe, G.M. et al., 2010. Development and characterisation of a collagen nanohydroxyapatite composite scaffold for bone tissue engineering. J Mater Sci Mater Med, 21(8), pp.2293-2298. Available at: http://www.ncbi.nlm.nih.gov/pubmed/20091099 [Accessed November 9, 2012].

Deponti, D. et al., 2014. Collagen Scaffold for Cartilage Tissue Engineering: The Benefit of Fibrin Glue and the Proper Culture Time in an Infant Cartilage Model. Tissue engineering. Part A, 20, pp.1113-1126. Available at: http://www.ncbi.nlm.nih.gov/pubmed/24152291 [Accessed March 3, 2014].

Discher, D.E., Janmey, P. \& Wang, Y.-L., 2005. Tissue cells feel and respond to the stiffness of their substrate. Science (New York, N.Y.), 310(5751), pp.1139-43. Available at: http://www.ncbi.nlm.nih.gov/pubmed/16293750 [Accessed May 23, 2014].

Eckert, C.E. et al., 2012. On the biomechanical role of glycosaminoglycans in the aortic heart valve leaflet. Acta biomaterialia, 9(1), pp.4653-60. Available at: http://www.ncbi.nlm.nih.gov/pubmed/23036945 [Accessed November 7, 2012].

Engler, A.J. et al., 2006. Matrix Elasticity Directs Stem Cell Lineage Specification. Cell, 126(4), pp.677-689. Available at: http://linkinghub.elsevier.com/retrieve/pii/S0092867406009615.

Eyrich, D. et al., 2007. Long-term stable fibrin gels for cartilage engineering. Biomaterials, 28(1), pp.55-65. Available at: http://www.ncbi.nlm.nih.gov/pubmed/16962167. 
Flanagan, T.C. et al., 2006. A collagen-glycosaminoglycan co-culture model for heart valve tissue engineering applications. Biomaterials, 27(10), pp.2233-2246. Available at: http://www.ncbi.nlm.nih.gov/pubmed/16313955.

Flanagan, T.C. et al., 2009. In vivo remodeling and structural characterization of fibrin-based tissue-engineered heart valves in the adult sheep model. Tissue Eng Part A, 15(10), pp.2965-2976. Available at: http://www.ncbi.nlm.nih.gov/pubmed/19320544.

Gleeson, J.P., Plunkett, N.A. \& O'Brien, F.J., 2010. Addition of hydroxyapatite improves stiffness, interconnectivity and osteogenic potential of a highly porous collagen-based scaffold for bone tissue regeneration. Eur Cell Mater, 20, pp.218-230. Available at: http://www.ncbi.nlm.nih.gov/pubmed/20922667.

Gundy, S. et al., 2008. Human coronary artery smooth muscle cell response to a novel PLA textile/fibrin gel composite scaffold. Acta biomaterialia, 4(6), pp.1734-44. Available at: http://www.ncbi.nlm.nih.gov/pubmed/18599374 [Accessed July 8, 2014].

Haisch, a et al., 2000. Preparation of a pure autologous biodegradable fibrin matrix for tissue engineering. Medical \& biological engineering \& computing, 38(6), pp.686-9. Available at: http://www.ncbi.nlm.nih.gov/pubmed/11217888 [Accessed July 24, 2013].

Harley, B.A.C. et al., 2007. Mechanical characterization of collagen-glycosaminoglycan scaffolds. Acta biomaterialia, 3(4), pp.463-74. Available at: http://www.ncbi.nlm.nih.gov/pubmed/17349829 [Accessed August 6, 2013].

Haugh, M.G. et al., 2011. Crosslinking and mechanical properties significantly influence cell attachment, proliferation, and migration within collagen glycosaminoglycan scaffolds. Tissue engineering. Part $A, 17(9-10)$, pp.1201-1208. Available at: http://online.liebertpub.com/doi/abs/10.1089/ten.tea.2010.0590 [Accessed June 23, 2014].

Haugh, M.G., Jaasma, M.J. \& O'Brien, F.J., 2009. The effect of dehydrothermal treatment on the mechanical and structural properties of collagen-GAG scaffolds. Journal of biomedical materials research. Part A, 89(2), pp.363-9. Available at: http://www.ncbi.nlm.nih.gov/pubmed/18431763 [Accessed August 27, 2014].

Haugh, M.G., Murphy, C.M. \& O’Brien, F.J., 2010. Novel freeze-drying methods to produce a range of collagen-glycosaminoglycan scaffolds with tailored mean pore sizes. Tissue Eng Part C Methods, 16(5), pp.887-894. Available at: http://www.ncbi.nlm.nih.gov/pubmed/19903089.

Hoerstrup, S.P. et al., 2002. Tissue Engineering of Functional Trileaflet Heart Valves From Human Marrow Stromal Cells. Circulation, 106(90121), pp.I-143-150. Available at: http://circ.ahajournals.org/cgi/content/abstract/106/12_suppl_1/l-143.

Hokugo, A., Takamoto, T. \& Tabata, Y., 2006. Preparation of hybrid scaffold from fibrin and biodegradable polymer fiber. Biomaterials, 27(1), pp.61-7. Available at: 
http://www.sciencedirect.com/science/article/B6TWB-4GJM3R9-

5/2/87c4156cd08bcccd1888a315d97c0eaf [Accessed June 14, 2014].

Jana, S. et al., 2014. Scaffolds for tissue engineering of cardiac valves. Acta Biomaterialia, 10(7), pp.2877-2893. Available at: http://www.sciencedirect.com/science/article/pii/S1742706114001251 [Accessed August 21, 2014].

Jockenhoevel, S. et al., 2001. Tissue engineering: complete autologous valve conduit--a new moulding technique. The Thoracic and cardiovascular surgeon, 49(5), pp.287-90. Available at: http://www.ncbi.nlm.nih.gov/pubmed/11605139 [Accessed February 21, 2014].

Kalfa, D. et al., 2010. A polydioxanone electrospun valved patch to replace the right ventricular outflow tract in a growing lamb model. Biomaterials, 31(14), pp.4056-63. Available at: http://www.sciencedirect.com/science/article/pii/S0142961210001833 [Accessed March 28, 2014].

Keogh, M.B., O'Brien, F.J. \& Daly, J.S., 2010. Substrate stiffness and contractile behaviour modulate the functional maturation of osteoblasts on a collagen-GAG scaffold. Acta biomaterialia, 6(11), pp.4305-13. Available at: http://www.sciencedirect.com/science/article/pii/S1742706110002667 [Accessed July 9, 2014].

Kim, B.-S. et al., 1998. Optimizing seeding and culture methods to engineer smooth muscle tissue on biodegradable polymer matrices. Biotechnology and bioengineering, 57(1), pp.46-54. Available at: http://www.ncbi.nlm.nih.gov/pubmed/10099177 [Accessed July 1, 2014].

Lee, F. \& Kurisawa, M., 2013. Formation and stability of interpenetrating polymer network hydrogels consisting of fibrin and hyaluronic acid for tissue engineering. Acta biomaterialia, 9(2), pp.5143-52. Available at:

http://www.sciencedirect.com/science/article/pii/S1742706112004126 [Accessed February 20, 2014].

Legant, W.R. et al., 2009. Microfabricated tissue gauges to measure and manipulate forces from 3D microtissues. Proceedings of the National Academy of Sciences of the United States of America, 106(25), pp.10097-102. Available at: http://www.pnas.org/content/106/25/10097.long [Accessed June 23, 2014].

Lesman, A. et al., 2011. Engineering vessel-like networks within multicellular fibrin-based constructs. Biomaterials, 32(31), pp.7856-69. Available at: http://www.ncbi.nlm.nih.gov/pubmed/21816465 [Accessed November 29, 2013].

Li, R.-K. et al., 2014. Biomaterials and cells for cardiac tissue engineering. In Cardiac Regeneration and Repair. pp. 127-179. Available at: http://www.sciencedirect.com/science/article/pii/B9780857096593500062. 
Merryman, W.D., Engelmayr, G.C., et al., 2006. Defining biomechanical endpoints for tissue engineered heart valve leaflets from native leaflet properties. Progress in Pediatric Cardiology, 21(2), pp.153-160. Available at:

http://linkinghub.elsevier.com/retrieve/pii/S1058981305000809 [Accessed June 24, 2014].

Merryman, W.D. et al., 2007. Differences in tissue-remodeling potential of aortic and pulmonary heart valve interstitial cells. Tissue engineering, 13(9), pp.2281-9. Available at: http://www.ncbi.nlm.nih.gov/pubmed/17596117 [Accessed January 23, 2014].

Merryman, W.D., Huang, H.Y., et al., 2006. The effects of cellular contraction on aortic valve leaflet flexural stiffness. J Biomech, 39(1), pp.88-96. Available at: http://www.ncbi.nlm.nih.gov/pubmed/16271591.

Misfeld, M. \& Sievers, H.-H., 2007. Heart valve macro- and microstructure. Philosophical transactions of the Royal Society of London. Series B, Biological sciences, 362(1484), pp.1421-36. Available at:

http://www.pubmedcentral.nih.gov/articlerender.fcgi?artid=2440405\&tool=pmcentrez \&rendertype=abstract [Accessed June 24, 2014].

Mol, A. et al., 2006. Autologous human tissue-engineered heart valves: prospects for systemic application. Circulation, 114(1 Suppl), pp.I152-8. Available at: http://www.ncbi.nlm.nih.gov/pubmed/16820565.

Mol, A. et al., 2005. Fibrin as a cell carrier in cardiovascular tissue engineering applications. Biomaterials, 26(16), pp.3113-3121. Available at: http://www.ncbi.nlm.nih.gov/pubmed/15603806.

Monfoulet, L. et al., 2014. The pH in the Microenvironment of Human Mesenchymal Stem Cells Is a Critical Factor for Optimal Osteogenesis in Tissue-Engineered Constructs. Tissue engineering. Part A, 20(13-14), pp.1827-1840. Available at: http://www.ncbi.nlm.nih.gov/pubmed/24447025 [Accessed July 11, 2014].

Moreira, R. et al., 2014. TexMi: Development of Tissue-Engineered Textile-Reinforced Mitral Valve Prosthesis. Tissue engineering. Part $C$, Methods, pp.1-8. Available at: http://www.ncbi.nlm.nih.gov/pubmed/24665896 [Accessed September 4, 2014].

Murphy, C.M. \& O'Brien, F.J., 2010. Understanding the effect of mean pore size on cell activity in collagen-glycosaminoglycan scaffolds. Cell Adh Migr, 4(3), pp.377-381. Available at: http://www.ncbi.nlm.nih.gov/pubmed/20421733.

Neidert, M.R. \& Tranquillo, R.T., 2006. Tissue-engineered valves with commissural alignment. Tissue engineering, 12(4), pp.891-903. Available at: http://www.ncbi.nlm.nih.gov/pubmed/16674301.

O'Brien, F.J. et al., 2004. Influence of freezing rate on pore structure in freeze-dried collagen-GAG scaffolds. Biomaterials, 25(6), pp.1077-1086. Available at: 
http://linkinghub.elsevier.com/retrieve/pii/S0142961203006306 [Accessed November 9, 2012].

O'Brien, F.J. et al., 2005. The effect of pore size on cell adhesion in collagen-GAG scaffolds. Biomaterials, 26(4), pp.433-41. Available at: http://www.ncbi.nlm.nih.gov/pubmed/15275817 [Accessed August 11, 2014].

Person, A.D., Klewer, S.E. \& Runyan, R.B., 2005. Cell biology of cardiac cushion development. International review of cytology, 243, pp.287-335. Available at: http://www.ncbi.nlm.nih.gov/pubmed/15797462 [Accessed July 10, 2014].

Pho, M. et al., 2008. Cofilin is a marker of myofibroblast differentiation in cells from porcine aortic cardiac valves. American journal of physiology. Heart and circulatory physiology, 294(4), pp.H1767-78. Available at: http://www.ncbi.nlm.nih.gov/pubmed/18263709 [Accessed June 1, 2014].

Ramaswamy, S. et al., 2010. The role of organ level conditioning on the promotion of engineered heart valve tissue development in-vitro using mesenchymal stem cells. Biomaterials, 31(6), pp.1114-25. Available at:

http://www.sciencedirect.com/science/article/pii/S0142961209011065 [Accessed June $25,2014]$.

Roche, E.T. et al., 2014. Comparison of biomaterial delivery vehicles for improving acute retention of stem cells in the infarcted heart. Biomaterials, 35(25), pp.6850-8. Available at: http://www.sciencedirect.com/science/article/pii/S0142961214005274 [Accessed July 9, 2014].

Rowe, S.L., Lee, S. \& Stegemann, J.P., 2007. Influence of thrombin concentration on the mechanical and morphological properties of cell-seeded fibrin hydrogels. Acta biomaterialia, 3(1), pp.59-67. Available at: http://www.sciencedirect.com/science/article/pii/S1742706106000997 [Accessed March 24, 2014].

Sant, S. et al., 2013. Effect of biodegradation and de novo matrix synthesis on the mechanical properties of valvular interstitial cell-seeded polyglycerol sebacatepolycaprolactone scaffolds. Acta biomaterialia, 9(4), pp.5963-73. Available at: http://www.sciencedirect.com/science/article/pii/S1742706112005533 [Accessed February 24, 2014].

Schmidt, D. et al., 2010. Minimally-invasive implantation of living tissue engineered heart valves: a comprehensive approach from autologous vascular cells to stem cells. Journal of the American College of Cardiology, 56(6), pp.510-20. Available at: http://www.ncbi.nlm.nih.gov/pubmed/20670763 [Accessed February 2, 2014].

Shah, D.N., Recktenwall-Work, S.M. \& Anseth, K.S., 2008. The effect of bioactive hydrogels on the secretion of extracellular matrix molecules by valvular interstitial cells. Biomaterials, 29(13), pp.2060-72. Available at: 
http://www.sciencedirect.com/science/article/pii/S0142961208000215 [Accessed March 30, 2014].

Sheu, M.T. et al., 2001. Characterization of collagen gel solutions and collagen matrices for cell culture. Biomaterials, 22(13), pp.1713-9. Available at: http://www.ncbi.nlm.nih.gov/pubmed/11396874.

Shikanov, A. et al., 2009. Interpenetrating fibrin-alginate matrices for in vitro ovarian follicle development. Biomaterials, 30(29), pp.5476-85. Available at: http://www.pubmedcentral.nih.gov/articlerender.fcgi?artid=2906124\&tool=pmcentrez \&rendertype=abstract [Accessed May 27, 2014].

Sodian, R. et al., 2000. Early In Vivo Experience With Tissue-Engineered Trileaflet Heart Valves. Circulation, 102(Supplement 3), pp.III-22-III-29. Available at: http://circ.ahajournals.org/cgi/doi/10.1161/01.CIR.102.suppl_3.III-22 [Accessed July 1, 2014].

Sung, H.-J. et al., 2004. The effect of scaffold degradation rate on three-dimensional cell growth and angiogenesis. Biomaterials, 25(26), pp.5735-42. Available at: http://www.ncbi.nlm.nih.gov/pubmed/15147819 [Accessed March 30, 2014].

Van Susante JLC et al., 2001. Linkage of chondroitin-sulfate to type I collagen scaffolds stimulates the bioactivity of seeded chondrocytes in vitro. Biomaterials, 22(17), pp.2359-69. Available at: http://www.ncbi.nlm.nih.gov/pubmed/11511033 [Accessed October 20, 2014].

Syedain, Z.H. et al., 2009. Controlled compaction with ruthenium-catalyzed photochemical cross-linking of fibrin-based engineered connective tissue. Biomaterials, 30(35), pp.6695-701. Available at: http://www.pubmedcentral.nih.gov/articlerender.fcgi?artid=2853233\&tool=pmcentrez \&rendertype=abstract [Accessed June 24, 2014].

Syedain, Z.H. et al., 2011. Implantation of a Tissue-engineered Heart Valve from Human Fibroblasts Exhibiting Short Term Function in the Sheep Pulmonary Artery. Cardiovascular Engineering and Technology, 2(2), pp.101-112. Available at: http://link.springer.com/10.1007/s13239-011-0039-5 [Accessed March 25, 2014].

Syedain, Z.H. et al., 2013. Tubular heart valves from decellularized engineered tissue. Annals of biomedical engineering, 41(12), pp.2645-54. Available at: http://www.ncbi.nlm.nih.gov/pubmed/23897047 [Accessed September 22, 2014].

Tierney, C.M. et al., 2009. The effects of collagen concentration and crosslink density on the biological, structural and mechanical properties of collagen-GAG scaffolds for bone tissue engineering. Journal of the Mechanical Behavior of Biomedical Materials, 2(2), pp.202-209. Available at: http://www.sciencedirect.com/science/article/B8G3J4TKPVKF-1/2/52f4add091ce21f82fb8cf62a247ab9e. 
Tierney, E.G. et al., 2012. The development of non-viral gene-activated matrices for bone regeneration using polyethyleneimine (PEI) and collagen-based scaffolds. Journal of controlled release : official journal of the Controlled Release Society, 158(2), pp.304-11. Available at: http://www.ncbi.nlm.nih.gov/pubmed/22138069 [Accessed June 18, 2013].

Van Vlimmeren, M.A.A. et al., 2013. The potential of prolonged tissue culture to reduce stress generation and retraction in engineered heart valve tissues. Tissue engineering. Part C, Methods, 19(3), pp.205-15. Available at: http://www.ncbi.nlm.nih.gov/pubmed/22889149 [Accessed July 8, 2014].

Weber, B. et al., 2013. Off-the-shelf human decellularized tissue-engineered heart valves in a non-human primate model. Biomaterials, 34(30), pp.7269-7280. Available at: http://www.sciencedirect.com/science/article/pii/S0142961213005334 [Accessed October 30, 2013].

Weinandy, S. et al., 2014. Biofunctionalized Microfiber-Assisted Formation of Intrinsic Three-Dimensional Capillary-Like Structures. Tissue engineering. Part A, 20(13-14), pp.1858-1869. Available at: http://www.ncbi.nlm.nih.gov/pubmed/24456033 [Accessed July 11, 2014].

Wyss, K. et al., 2012. The elastic properties of valve interstitial cells undergoing pathological differentiation. Journal of Biomechanics, 45(5), pp.882-887. Available at: http://www.sciencedirect.com/science/article/pii/S0021929011007123.

Yamanami, M. et al., 2010. Development of a completely autologous valved conduit with the sinus of Valsalva using in-body tissue architecture technology: a pilot study in pulmonary valve replacement in a beagle model. Circulation, 122(11 Suppl), pp.S100-6. Available at: http://www.ncbi.nlm.nih.gov/pubmed/20837900 [Accessed March 28, 2014].

Ye, Q., Zünd, G., Benedikt, P., et al., 2000. Fibrin gel as a three dimensional matrix in cardiovascular tissue engineering. European Journal of Cardio-Thoracic Surgery, 17(5), pp.587-591. Available at: http://www.sciencedirect.com/science/article/B6T35408BKOK-J/2/76b229125ad2d35920c2bfbc041a6057.

Ye, Q., Zünd, G., Jockenhoevel, S., et al., 2000. Scaffold precoating with human autologous extracellular matrix for improved cell attachment in cardiovascular tissue engineering. ASAIO J, 46(6), pp.730-733. Available at: http://www.ncbi.nlm.nih.gov/pubmed/11110271.

Yip, C.Y.Y. et al., 2009. Calcification by valve interstitial cells is regulated by the stiffness of the extracellular matrix. Arteriosclerosis, thrombosis, and vascular biology, 29(6), pp.936-42. Available at: http://atvb.ahajournals.org/content/29/6/936.long [Accessed June 23, 2014].

Zund, G. et al., 1999. Tissue engineering in cardiovascular surgery: MTT, a rapid and reliable quantitative method to assess the optimal human cell seeding on polymeric meshes. 
European journal of cardio-thoracic surgery : official journal of the European Association for Cardio-thoracic Surgery, 15(4), pp.519-24. Available at:

http://www.ncbi.nlm.nih.gov/pubmed/10371132 [Accessed July 1, 2014]. 


\section{Figure Captions}

Figure 1: Methods of producing fibrin-collagen-glycosaminoglycan (FCG) scaffolds. The CG structure is a freeze-dried crosslinked matrix to which fibrin is added. For both the drop-loading or injection method the first three fibrin ingredients $\left(\mathrm{CaCl}_{2}\right.$, thrombin and TBS) are first added to the CG matrix. For the drop-loading method, fibrinogen is added in a second step by being dropped on top of the matrix. For the injection method, fibrinogen ( \& cells) is injected using a 27 gauge syringe into the CG matrix, in a circular pattern. The injection method produced more consistent FCG scaffolds.

Figure 2: The injection method of fibrin incorporation showed a more homogenous fibrin distribution through the Collagen-Glycosaminoglycan (CG) matrix than the drop loading method. (A) Masson's Trichrome (MT) staining of drop-loaded scaffolds showed uneven infiltration of fibrin (red) through the collagen glycosaminoglycan (CG) matrix (blue). (B) Scanning Electron Microscopy (SEM) confirmed this, revealing little fibrin evident within the CG matrix. (C) MT staining of injection

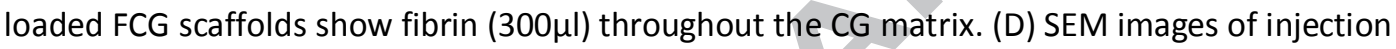
loaded scaffolds show fibrin and CG intermingled. (E) MT image where $350 \mu$ l of fibrin was injection loaded through the CG structure resulting in overloading of the CG structure with fibrin as seen by the large amount of fibrin which remained on top of the $C G$ structure. ( $N=3$ in all cases).

Figure 3: The compressive and tensile moduli of fibrin were significantly increased when fibrin was reinforced with a crosslinked collagen glycosaminoglycan (CG) matrix. (A) Compressive modulus of fibrin is significantly increased when incorporated into a CG structure. The compressive modulus of CG is significantly decreased when fibrin is incorporated. (B) The tensile modulus of CG and FCG were not significantly different from each other, but both were independently significant to fibrin alone. $\mathrm{N}=3$, for significant difference, $\mathrm{p}<0.05\left(^{*}\right)$.

Figure 4: Masson's Trichrome staining of fibrin-collagen-glycosaminoglycan (FCG) scaffolds, taken at day 3 (A \& B) and day 7 (C \& D) that show fibrin (red), collagen (blue) and cells (black) throughout the entire scaffold in both the longitudinal ( $\&$ \& $C$ ) and transverse (B \& D) planes. Images taken at day 5 are not shown here, but show the same detail. Scale bar represents $100 \mu \mathrm{m}$. $\mathrm{N}=3$.

Figure 5: Live/dead staining of vascular smooth muscle cells (VSMC) in a fibrin-collagenglycosaminoglycan (FCG) scaffold over 7 days, show excellent viability with very few dead cells (red) present. Live cells fluoresce green and are seen to increase in number from day 3 (A \& B) to days 5 (C \& D) and 7 (E \& F). All samples were seeded at the same seeding density of 1,000 cells per 
$\mathrm{mm}^{3}$ of scaffold. On day 3 , excellent viability is seen with space remaining within the scaffold structure. By Day 5 the cell number has increased, with very few dead cells evident. Day 7 showed scaffolds with confluent cell populations. As these samples were $2 \mathrm{~mm}$ deep, the images are picking up cells, both on the surface of the scaffold and cells within the scaffold. The deeper cells are out of focus in the images. $\mathrm{N}=3$ at each time point.

Figure 6: An increase in dsDNA is seen over the timepoints using PicoGreen assay, indicating that the vascular smooth muscle cells are proliferating in the fibrin-collagen-glycosaminoglycan (FCG) scaffold. Based on $p<0.05$ cell number was shown to be significantly higher at Day 5 than Day 0 and Day 3, and higher at Day 7 than Day $0\left({ }^{* *}\right)$. These results indicate that proliferation of the cells was occurring in the FCG scaffold. Results represent three independent samples tested in triplicate.

Figure 7: Fibrin-collagen-glycosaminoglycan (FCG) scaffolds resisted cell-mediated contraction in vitro, by vascular smooth muscle cells up to 7 days. As shown in (A), fibrin gels with the same seeding density had contracted to approximately $10 \%$ of their original diameter after 3 days. Graph shows mean \pm standard deviation. $\mathrm{N}=9$ for these tests. (B) Macro image of cell seeded fibrin gels at day 0 and subsequently following contraction, at day 7. (C) Macro image of FCG scaffold at day 0 , and (D) at day 7 where no contraction of the FCG scaffold had occurred. 


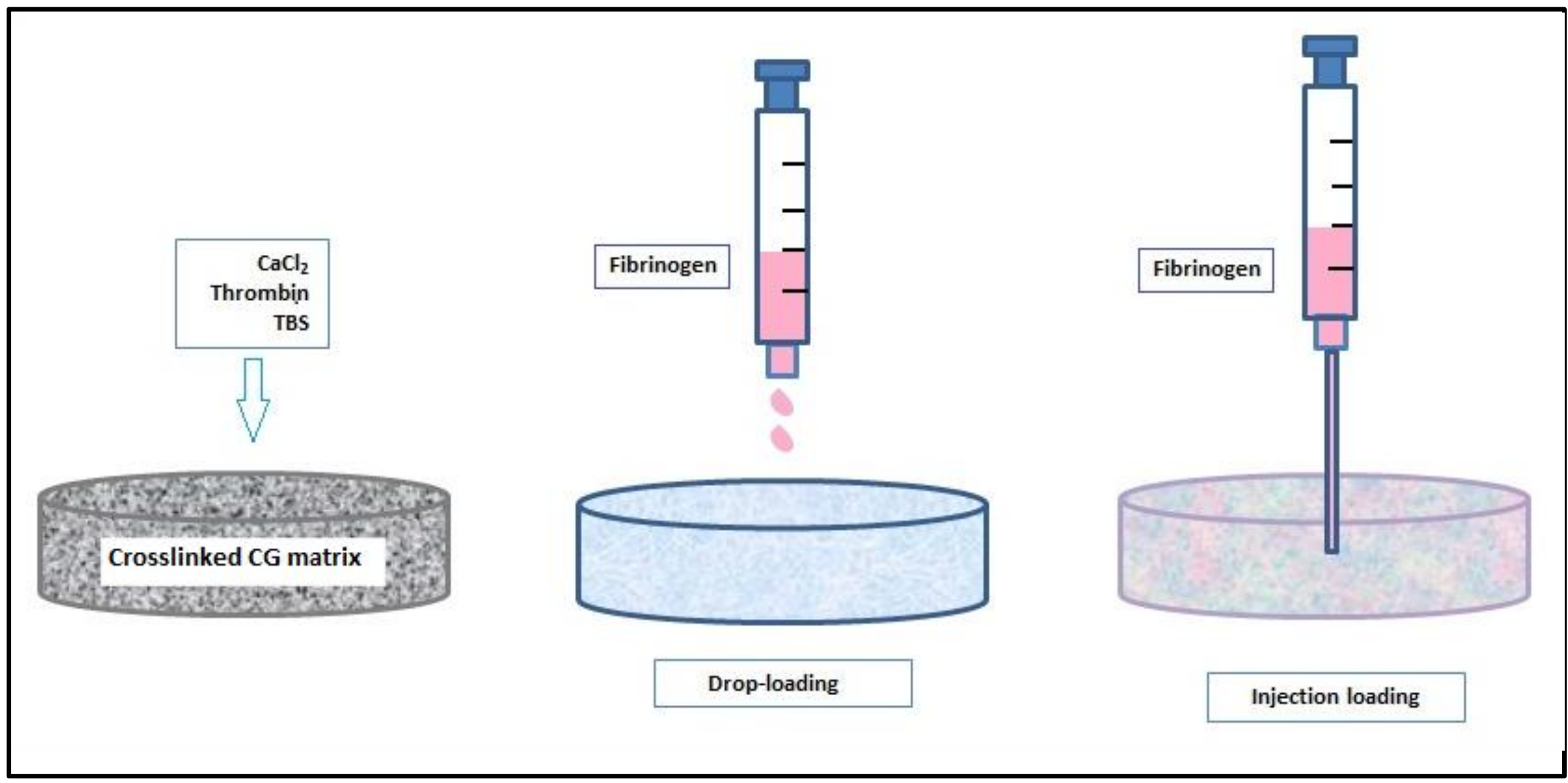

Figure 1: Methods of producing fibrin-collagen-glycosaminoglycan (FCG) scaffolds. The CG structure is a freeze-dried crosslinked matrix to which fibrin is added. For both the drop-loading or injection method the first three fibrin ingredients ( $\mathrm{CaCl}_{2}$, thrombin and TBS) are first added to the CG matrix. For the drop-loading method, fibrinogen is added in a second step by being dropped on top of the matrix. For the injection method, fibrinogen ( $\&$ cells) is injected using a 27 gauge syringe into the CG matrix, in a circular pattern. The injection method produced more consistent FCG scaffolds. 
A

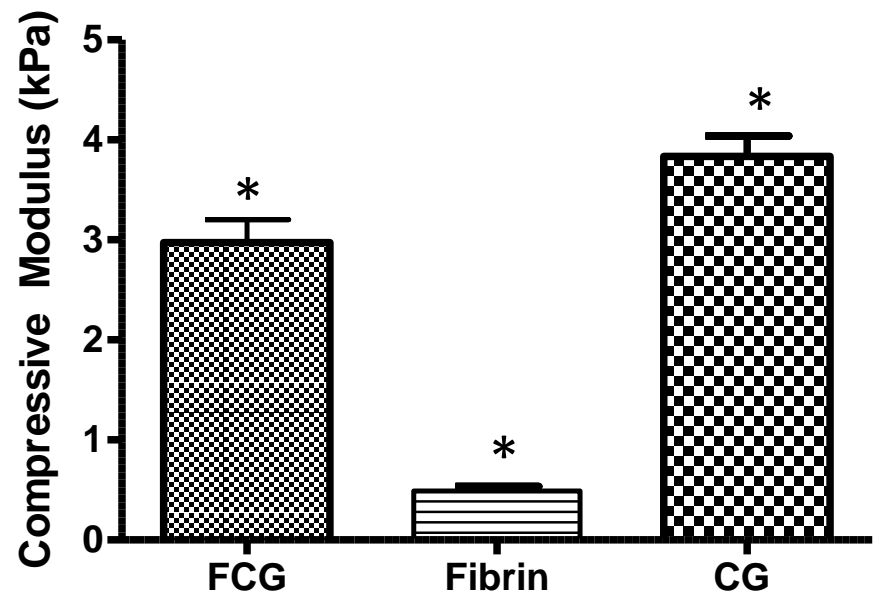

B

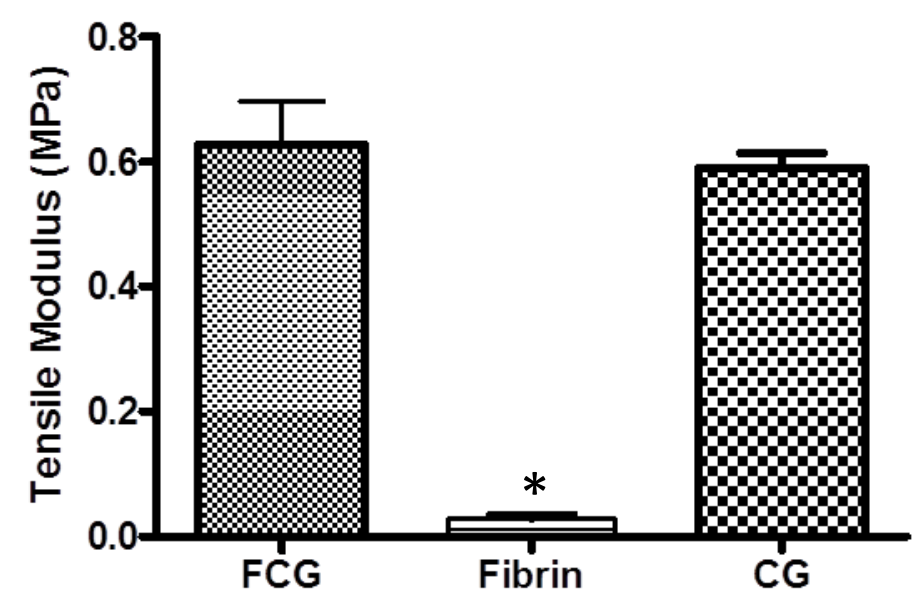

Figure 3: The compressive and tensile moduli of fibrin were significantly increased when fibrin was reinforced with a crosslinked collagen glycosaminoglycan (CG) matrix. (A) Compressive modulus of fibrin is significantly increased when incorporated into a CG structure. The compressive modulus of CG is significantly decreased when fibrin is incorporated. (B) The tensile modulus of CG and FCG were not significantly different from each other, but both were independently significant to fibrin alone. $\mathrm{N}=3$, for significant difference, $p<0.05(*)$. 


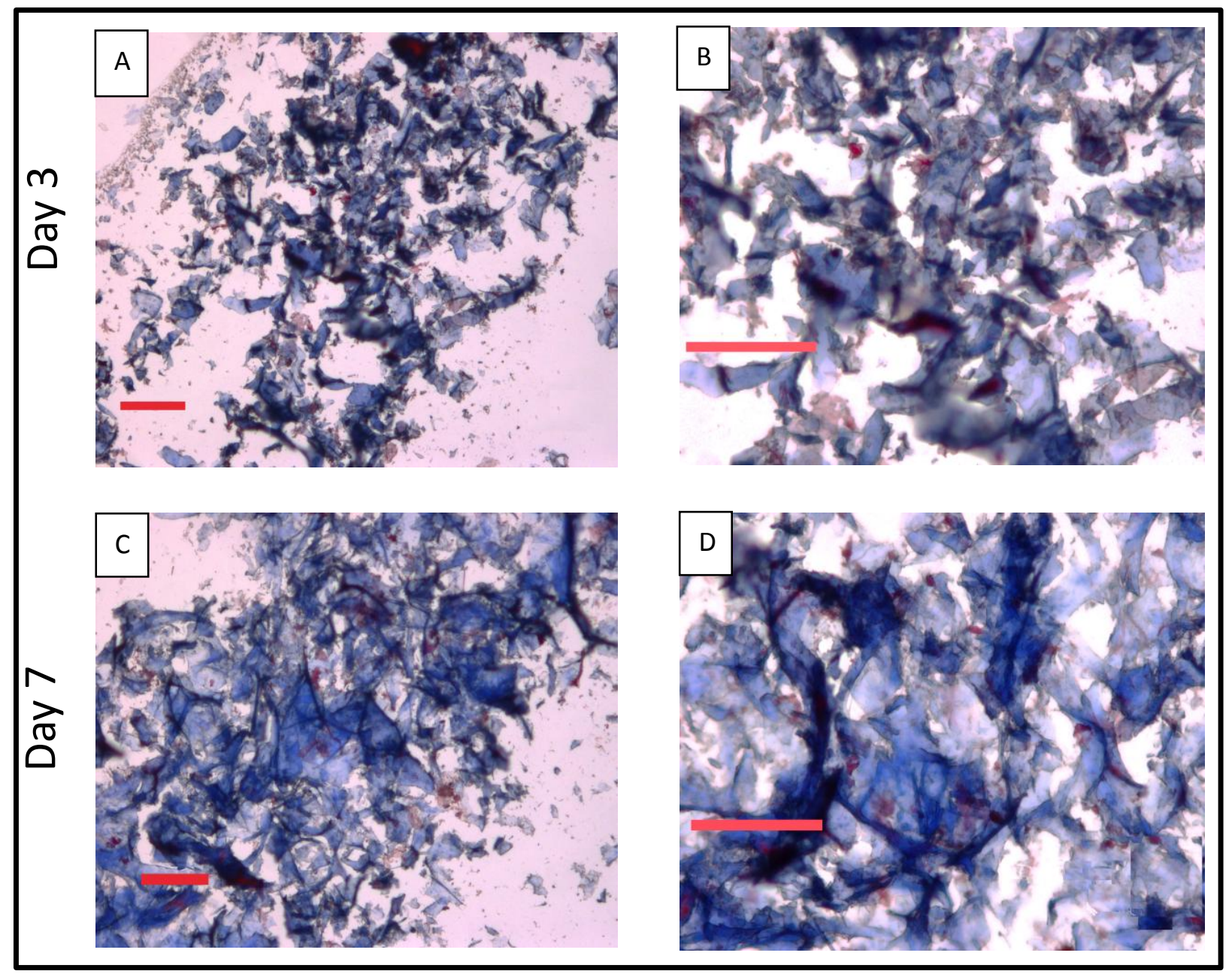

Figure 4: Masson's Trichrome staining of fibrin-collagen-glycosaminoglycan (FCG) scaffolds, taken at day 3 (A \& B) and day 7 (C \& D) that show fibrin (red), collagen (blue) and cells (black) throughout the entire scaffold in both the longitudinal (A \& C) and transverse (B \& D) planes. Images taken at day 5 are not shown here, but show the same detail. Scale bar represents $100 \mu \mathrm{m} . \mathrm{N}=3$. 


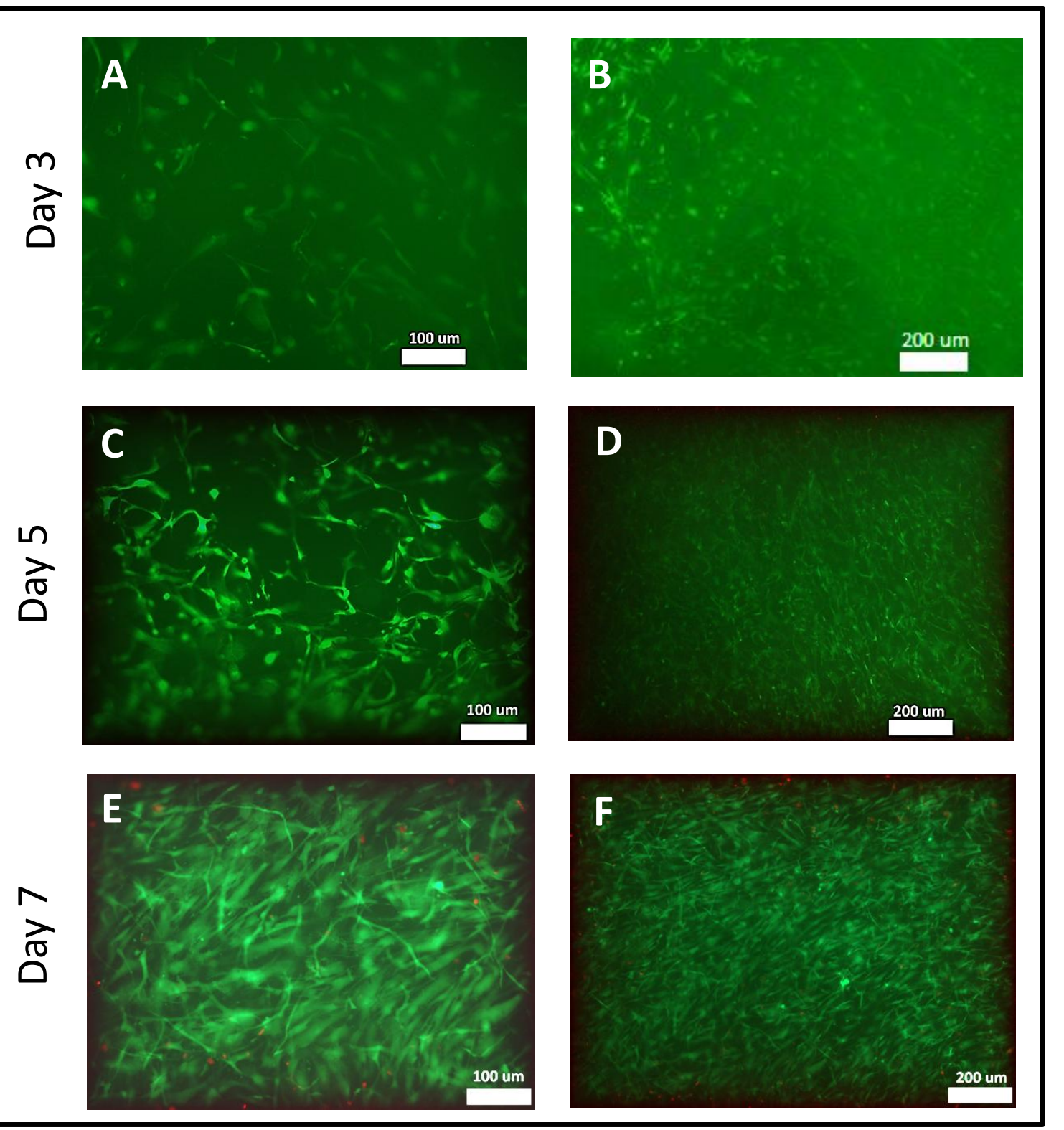

Figure 5: Live/dead staining of vascular smooth muscle cells (VSMC) in a fibrin-collagenglycosaminoglycan (FCG) scaffold over 7 days, show excellent viability with very few dead cells (red) present. Live cells fluoresce green and are seen to increase in number from day $3(A \& B)$ to days 5 ( C \& $D)$ and 7 (E \& F). All samples were seeded the same seeding density of 1,000 cells per $\mathrm{mm}^{3}$ of scaffold. On day 3 , excellent viability is seen with space remaining within the scaffold structure. By Day 5 the cell number has increased, with very few dead cells evident. Day 7 showed scaffolds with confluent cell populations. As these samples were $2 \mathrm{~mm}$ deep, the images are picking up cells, both on the surface of the scaffold and cells within the scaffold. The deeper cells are out of focus in the images. $\mathrm{N}=3$ at each time point. 


\section{Cell number based on DNA flourescence}

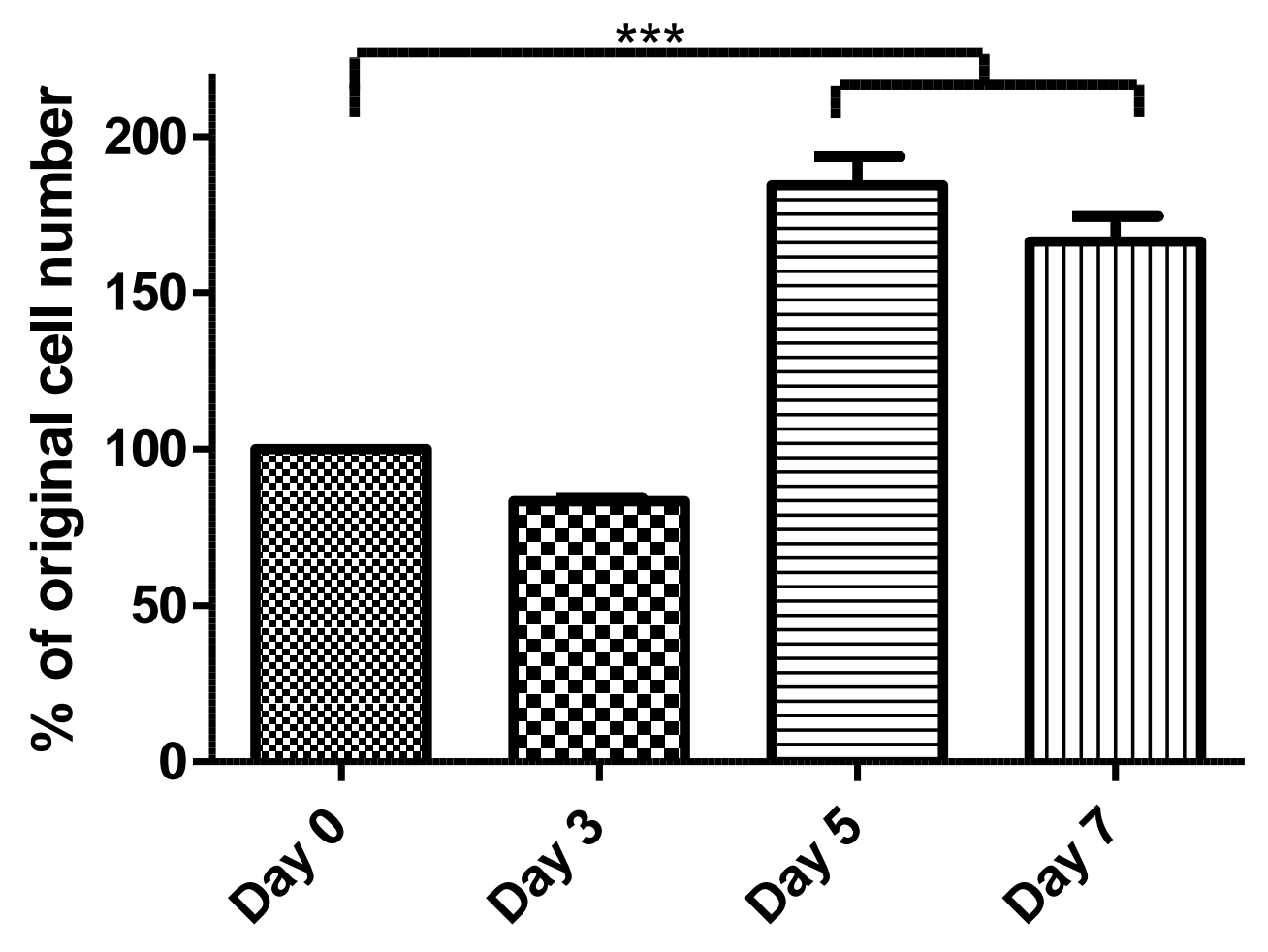

Figure 6: An increase in dsDNA is seen over the timepoints using PicoGreen assay, indicating that the vascular smooth muscle cells are proliferating in the fibrin-collagen-glycosaminoglycan (FCG) scaffold. Based on $p<0.05$ cell number was shown to be significantly higher at Day 5 than Day 0 and Day 3, and higher at Day 7 than Day $0\left({ }^{* *}\right)$. These results indicate that proliferation of the cells was occurring in the FCG scaffold. Results represent three independent samples tested in triplicate. 
A

\section{0}

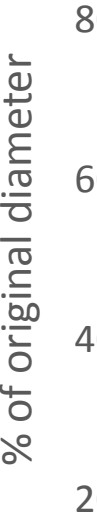

60

40

20

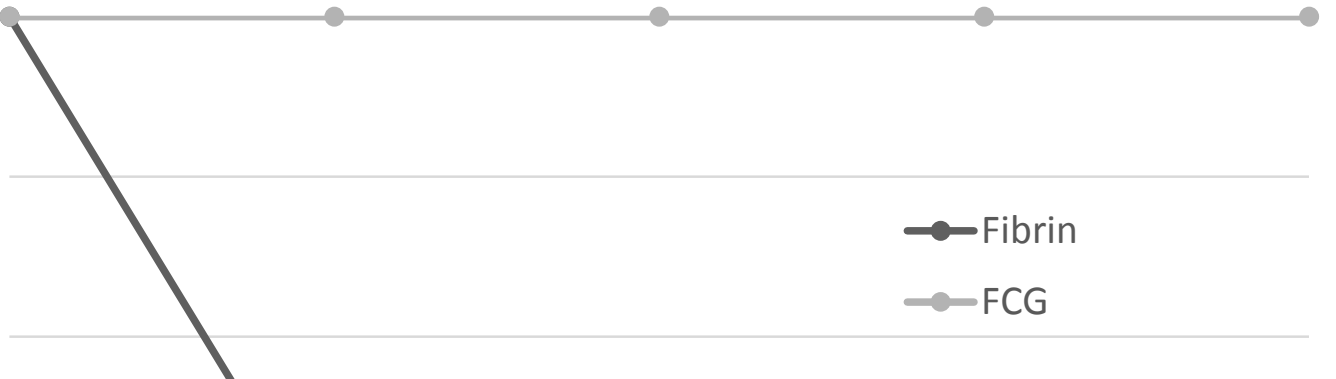

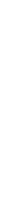

0
Day 0
Day 1
Day 3
Day 5
Day 7

Figure 7: Fibrin-collagen-glycosaminoglycan (FCG) scaffolds resisted cell-mediated contraction in vitro, by vascular smooth muscle cells up to 7 days. As shown in (A), fibrin gels with the same seeding density had contracted to approximately $10 \%$ of their original diameter after 3 days. Graph shows mean \pm standard deviation. $\mathrm{N}=9$ for these tests. (B) Macro image of cell seeded fibrin gels at day 0 and subsequently following contraction, at day 7. (C) Macro image of FCG scaffold at day 0 , and (D) at day 7 where no contraction of the FCG scaffold had occurred.

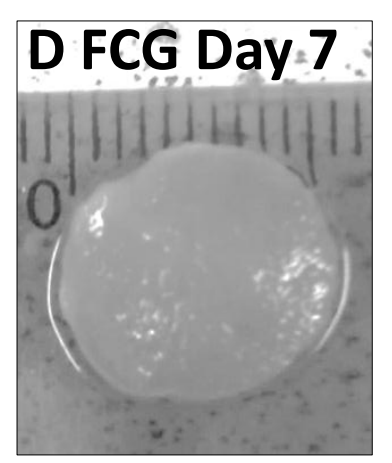




\section{Problem:}

Fibrin gels and cell mediated contraction

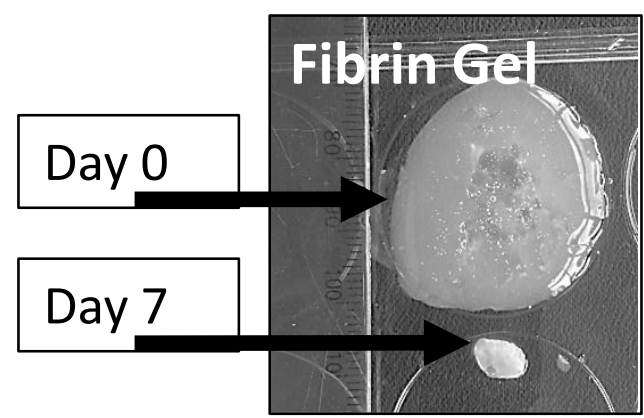

Solution:

Fibrin-collagen-glycosaminoglycan

(FCG) scaffold

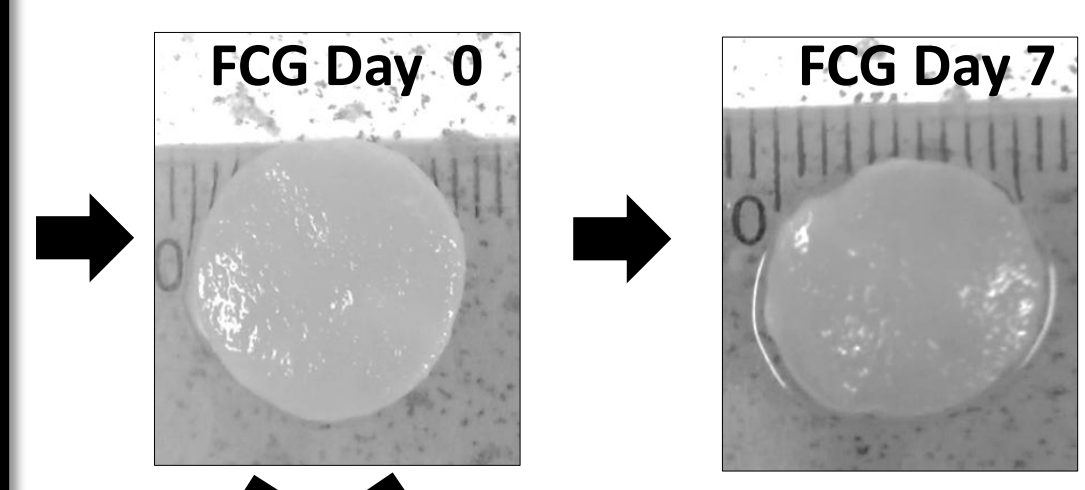

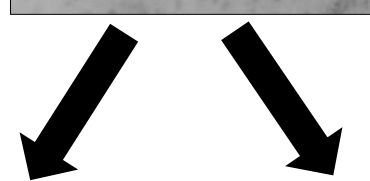

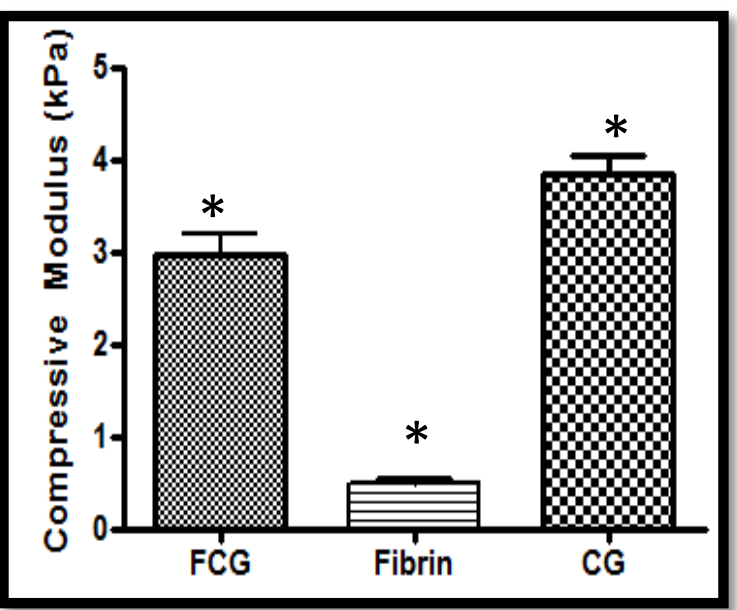

